\begin{tabular}{|c|c|}
\hline $\begin{array}{l}\text { Chemistry of } \\
\text { Metals and Allovs }\end{array}$ & 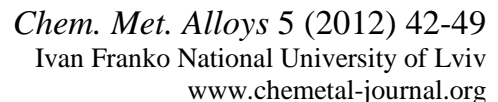 \\
\hline
\end{tabular}

\title{
Determination of ruthenium(III) in the presence of micellar medium by derivative spectrophotometric technique
}

\author{
M. RAMESWARA RAO ${ }^{1}$, K.B. CHANDRASEKHAR ${ }^{2}$, N. DEVANNA ${ }^{3}$ \\ ${ }^{1}$ Department of Quality Control, Chemical Technical Operations Unit-1, Dr. Reddy's Laboratories Pvt. Ltd, \\ Bollaram, Jinnaram, Medak (Dist) -502325, India \\ ${ }^{2}$ Department of Chemistry, Jawaharlal Nehru Technological University Anantapur, College of Engineering, \\ Anantapur-515002, Andhrapradesh, India \\ ${ }^{3}$ Oil Technological Research Institute, Jawaharlal Nehru Technological University Anantapur, \\ Anantapur-515002, Andhrapradesh, India \\ * Corresponding author.Tel.: +91-9885282328; e-mail: raamesh_1120@yahoo.co.in
}

Received April 13, 2012; accepted June 27, 2012; available on-line November 5, 2012

A sensitive spectrophotometric method has been developed for the determination of ruthenium(III) using 3,5-dimethoxy-4-hydroxybenzaldehyde isonicotinoylhydrazone (DMHBIH) in presence of neutral miceller medium of Triton X-100. The metal ion forms a brownish yellow coloured water soluble complex with the DMHBIH reagent in acidic buffer $\mathrm{pH}$ 4.25. Spectral data shows the formation of an 1:1 (M:L) complex with a stability constant $1.82 \times 10^{6}$. Beer's law is obeyed over a concentration range of 0.202 to $4.043 \mu \mathrm{g} / \mathrm{mL}$ of Ru(III) at $390 \mathrm{~nm}$. The molar absorptivity and Sandell's sensitivity are calculated to be $1.7 \times 10^{4} \mathrm{~L} \cdot \mathrm{mol}^{-1} \cdot \mathrm{cm}^{-1}$ and $0.006 \mu \mathrm{g} . \mathrm{cm}^{-2} \mathrm{Ru}($ III) respectively. The developed derivative spectrophotometric method was employed for the determination of $\mathrm{Ru}(\mathrm{III})$ in synthetic alloy samples and real water samples. The effect of various diverse ions has also been studied.

Derivative spectrophotometry / Ruthenium(III) / 3,5-dimethoxy-4-hydroxybenzaldehyde isonicotinoylhydrazone (DMHBIH) / Synthetic alloy samples / Real water samples

\section{Introduction}

Ruthenium is a hard white metal. It does not transit at room temperature, but oxidizes explosively at high temperatures. The metal is not attacked by hot or cold acids or aqua-regia. The oxidation states of ruthenium range from +1 to +8 , though oxidation states of $+2,+3$ and +4 are most common. The chief source of ruthenium is osmiridium, in which it ranges from $0.2 \%$ to about $20 \%$. Ruthenium has highly effective ability to harden platinum and palladium and it is alloyed with these metals to make electrical contacts for severe wear resistance. The corrosion resistance of titanium is improved a hundred-fold by addition of $0.1 \%$ ruthenium. Ruthenium is used as a catalyst in some platinum alloys. The compound rutheniumtetroxide $\left(\mathrm{RuO}_{4}\right)$ is highly toxic similar to osmiumtetroxide $\left(\mathrm{OsO}_{4}\right)$ and may explode. Ruthenium does strongly stain human skin, may be carcinogenic and bio-accumulates in bone.

Hydrazones are important organic analytical reagents for the determination of metal ions in microgram quantities. They react with metal ions forming colour complexes and act as chelating agents. The potential applications of hydrazone derivatives for the spectrophotometric determination of metal ions have been reviewed by Singh et al. [1]. Few hydrazone reagents were used for the spectrophotometric determination of ruthenium(III) [2-5]. The great interest towards derivative spectrophotometry is due to the increased resolution of spectral bands, allowing the detection and location of the wavelengths of poorly resolved components of complex spectra and reducing the effect of spectral background interferences. Derivative spectrophotometric methods for the determination of metal ions are not exploited much [6-9]. In the light of the good analytical characteristics of hydrazones, herein we report zero, first and second order derivative spectrophotometric determination of $\quad \mathrm{Ru}$ (III) using 3,5-dimethoxy-4hydroxybenzaldehydeisonicotinoyl-hydrazone (DMHBIH) in presence of Triton X-100, a neutral (nonionic) surfactant medium. 


\section{Experimental}

\section{Apparatus}

A Shimadzu 160A, microcomputer-based UV-VIS spectrophotometer equipped with $1.0 \mathrm{~cm}$ quartz cells was used for all spectral measurements. The instrumental parameters were optimized and the best results were obtained with a scan speed of $145 \mathrm{~nm} / \mathrm{min}$, slit width of $1.0 \mathrm{~nm}$ and $\Delta \lambda=2 \mathrm{~nm}$ for the first order derivative mode in the wavelength range $350 \mathrm{~nm}$ to $650 \mathrm{~nm}$. An ELICO LI-120 digital $\mathrm{pH}$-meter was used for the $\mathrm{pH}$ adjustments. The reproducibility of the measurements is within $0.01 \mathrm{pH}$. Sartorius BS/BT 2245 model (Germany make) electronic analytical balance having maximum capacity of $220 \mathrm{~g}$ and sensitivity of $\pm 0.1 \mathrm{mg}$ was used for weighing purpose.

\section{Reagents}

All chemicals used were of A.R. grade unless stated. All solutions were prepared with distilled water.

\section{Ruthenium(III) stock solution}

The standard ruthenium(III) solution $\left(1 \times 10^{-2} \mathrm{M}\right)$ was prepared by dissolving $0.2076 \mathrm{~g}$ of ruthenium chloride $\left(\mathrm{RuCl}_{3}\right.$ A.R. LOBA) in minimum amount of dilute hydrochloric acid and diluted up to the mark using distilled water in a $100-\mathrm{mL}$ standard flask. The stock solution was standardized spectrophotometrically [10].

\section{Triton $X-100$ solution}

Aqueous solution of 5\% Triton X-100 was prepared by diluting $5.0 \mathrm{~mL}$ of Triton X-100 (GR Merck) to $100 \mathrm{~mL}$ with distilled water.

\section{Buffer Solutions}

Buffer solutions were prepared by $1.0 \mathrm{M}$ hydrochloric acid - 1.0 M sodium acetate ( $\mathrm{pH} 0.5-3.5) ; 0.2 \mathrm{M}$ acetic acid - 0.2 M sodium acetate ( $\mathrm{pH} 4.5-7.0)$; $0.25 \mathrm{M}$ sodium tetraborate decahydrate $-0.1 \mathrm{M}$ hydrochloric acid ( $\mathrm{pH} \quad 8.0-9.1$ ); $0.25 \mathrm{M}$ sodium tetraborate decahydrate $-0.1 \mathrm{M}$ sodium hydroxide $(\mathrm{pH}$ 9.2-10.8). Solutions of various diverse ions of suitable concentrations were prepared using A.R. grade chemicals.

\section{Synthesis of 3,5-dimethoxy-4-hydroxybenzaldehyde isonicotinoylhydrazone (DMHBIH)}

The reagent 3,5-dimethoxy-4-hydroxybenzaldehyde isonicotinoylhydrazone (DMHBIH) was synthesized by refluxing equimolar amounts of 3,5-dimethoxy4-hydroxy benzaldehyde and isonicotinoylhydrazide. In a $250-\mathrm{mL}$ round bottom flask hot ethanolic solutions of 3,5-dimethoxy-4-hydroxybenzaldehyde $(1.8218 \mathrm{~g}, \quad 0.01 \mathrm{~mole})$ and isonicotinoylhydrazide ( $1.3714 \mathrm{~g}, 0.01 \mathrm{~mole})$ are mixed and refluxed using a water condenser for $5 \mathrm{~h}$. On cooling the reaction mixture, a light greenish coloured crystalline product was separated out, collected by filtration and washed several times with $(20 \%)$ ethanol in water and dried in vacuo. The resulting hydrazone was re-crystallized by using ethanol (yield, $76 \%$; $\mathrm{mp} 221^{\circ} \mathrm{C}$ ).

The infrared spectrum of the reagent shows bands at $v\left(\mathrm{~cm}^{-1}\right) 3429.03(\mathrm{NH}), 2924.16(\mathrm{OH}), 1658.62$ $(>\mathrm{C}=\mathrm{O}), \quad 1578.92 \quad(\mathrm{C}=\mathrm{N}), \quad 1514.12 \quad(\mathrm{C}=\mathrm{N}$ pyridine ring), 1372.71 (N-H primary amide). The ${ }^{1} \mathrm{H}$ NMR (200 MHz) spectrum of the reagent was recorded in DMSO solvent. It shows signals corresponding to $\delta 11.9$ (s, 1H, NH), 8.97 (s, 1H, OH phenolic), 8.78 (d, 2H, ArH pyridine ring), $8.34(\mathrm{~s}, 1 \mathrm{H}, \mathrm{N}=\mathrm{C}-\mathrm{H}), 7.8$ (d, 2H, ArH pyridine ring), 7.01 (s, 2H, ArH aldehydic), $3.8\left(\mathrm{~s}, 6 \mathrm{H},-\mathrm{OCH}_{3}\right.$ (2 methoxy)), 3.3 (s, 2H, water in solvent), 2.5 (s, 6H, DMSO solvent). The mass spectrum shows a molecular ion peak at $\mathrm{m} / \mathrm{z}$ $302.2(\mathrm{M}+1)$. The structure of DMHBIH was confirmed based upon above IR, NMR and mass spectral data, given in Fig. 1. The product is sparingly soluble in methanol but easily soluble in dimethylformamide (DMF) and dimethylsulfoxide (DMSO). Hence, reagent stock solution $(0.01 \mathrm{M})$ was prepared by dissolving $301.30 \mathrm{mg}$ of DMHBIH in $100 \mathrm{~mL}$ of DMF. The reagent solution is stable for $48 \mathrm{~h}$.<smiles>COc1cc(/C=N/NC(=O)c2ccncc2)cc(OC)c1O</smiles>

Fig. 1 Structure of 3,5-dimethoxy-4hydroxybenzaldehyde isonicotinoylhydrazone (DMHBIH).

\section{Analytical properties of DMHBIH}

The reactions of some important metal ions were tested at different $\mathrm{pH}$ values. The samples were prepared in $25-\mathrm{mL}$ volumetric flasks by adding $10 \mathrm{~mL}$ of buffer solution ( $\mathrm{pH} 1.0-11.0$ ), $0.5 \mathrm{~mL}$ of $1 \times 10^{-3} \mathrm{M}$ metal ion, $1.0 \mathrm{~mL}$ of Triton $\mathrm{X}-100(5 \%)$ and $0.5 \mathrm{~mL}$ of $1 \times 10^{-2} \mathrm{M}$ DMHBIH reagent solution. The mixture was diluted up to the mark with distilled water. The absorbance was measured in the $350-700 \mathrm{~nm}$ range against reagent blank. The results are summarized in Table 1.

\section{Recommended procedures}

\section{Determination of ruthenium(III) (zero order)}

An aliquot of the solution containing 0.202 to $4.043 \mu \mathrm{g} / \mathrm{mL}$ of $\mathrm{Ru}(\mathrm{III}), 10 \mathrm{~mL}$ of buffer $\mathrm{pH} 4.25$, $1.0 \mathrm{~mL}$ of Triton X-100 (5\%) and $1.0 \mathrm{~mL}$ of DMHBIH reagent $1 \times 10^{-2} \mathrm{M}$ were taken in a $25-\mathrm{mL}$ volumetric flask and the solution was diluted up to the mark with distilled water. The absorbance of the solution was recorded at $390 \mathrm{~nm}$ in a $1.0-\mathrm{cm}$ cell 
against reagent blank prepared in the same way but without metal ion. The measured absorbance was used to compute the amount of ruthenium(III) from the calibration plot.

Determination of Ru(III) by first order derivative spectrophotometry

For the above solution of Ru(III)-DMHBIH a first order derivative spectrum was recorded with a scan speed having degrees of freedom 9 in the wavelength range $350 \mathrm{~nm}$ to $600 \mathrm{~nm}$. The first order derivative peak height $(h)$ was measured by the peak-zero method at $426 \mathrm{~nm}$. The peak height was plotted against the amount of $\mathrm{Ru}$ (III) to obtain the calibration curve.

Determination of $R u(I I I)$ by second order derivative spectrophotometry

For the above solution, second order derivative spectrum of Ru(III)-DMHBIH system was recorded with reference to reagent blank in the wavelength range $350 \mathrm{~nm}$ to $600 \mathrm{~nm}$. In the second order derivative spectrum the peak height at $438 \mathrm{~nm}$ was measured from the zero line of the spectrum. Calibration plots were constructed by plotting the derivative amplitude against the amounts of ruthenium(III).

\section{Analysis of alloy samples}

$0.5 \mathrm{~g}$ sample of alloy was digested in $15 \mathrm{~mL}$ of aquaregia by warming and the solution was evaporated to dryness. The residue was dissolved in $10 \mathrm{~mL}$ of diluted $\mathrm{HCl}$ and the resulting solution concentrated to $5.0 \mathrm{~mL}$, diluted to $50 \mathrm{~mL}$ with distilled water, filtered and made up to the mark in a $100-\mathrm{mL}$ volumetric flask.

\section{Real water samples}

Each filtered (with whatman No. 40) river water sample $(250 \mathrm{~mL})$ was mixed with $10 \mathrm{~mL}$ of concentrated nitric acid in a 500-mL distillation flask. The sample was digested in the presence of excess potassium permanganate solution according to the method recommended by Fifield et al. [11]. The solution was cooled and neutralized with a dilute $\mathrm{NH}_{4} \mathrm{OH}$ solution. The digest was transferred into a 25-mL standard flask and diluted up to the mark with distilled water.

\section{Results and discussion}

The reagent DMHBIH was easily synthesized as any other Schiff base reagent. So far the new chromogenic reagent DMHBIH was not used for the determination of $\mathrm{Ru}(\mathrm{III})$. The de-protonation constants of DMHBIH have been determined by recording UV-Visible spectra of $\mu \mathrm{M}\left(1.2 \times 10^{-6} \mathrm{M}\right)$ at various $\mathrm{pH}$ values [12] and by taking the arithmetic mean of the values obtained from the measurements at five different wavelengths. The values of de-protonation of the ligand are $5.1\left(\mathrm{pK}_{1}\right)$ and $8.2\left(\mathrm{pK}_{2}\right)$. The possible species that may be formed at different $\mathrm{pH}$ values are shown in Fig. 2.<smiles>C#CC#Cc1ccncc1C(=O)N/N=C/c1cc(OC)c(O)c(OC)c1</smiles>

Enolic form<smiles>COc1cc(/C=N/NC([O+])c2ccnc(/C=N/NC([OH2+])c3ccncc3)c2)cc(OC)c1O</smiles>

Mono-ionic form

Fig. 2 Different species of DMHBIH at different $\mathrm{pH}$ values. 
In acidic medium, the ligand presumably exists in enolic form and co-ordinates the metal ion as monoanion to give neutral complexes. The colour reactions of some important metal ions with DMHBIH are summarized in Table 1 . The colour reactions are mainly due to complex formation of DMHBIH with divalent, trivalent metal ions such as $\mathrm{Pd}(\mathrm{II}), \mathrm{Cu}(\mathrm{II})$ $\mathrm{Au}(\mathrm{III})$ and $\mathrm{Ru}(\mathrm{III})$ in acidic medium to give intense coloured complexes.

\section{Absorption spectra}

The absorption spectra of the DMHBIH reagent and [Ru(III)-DMHBIH] complex recorded in optimum conditions against buffer solution and reagent blank, respectively, are shown in Fig. 3. The complex shows absorption maximum at an analytical wavelength of $390 \mathrm{~nm}$, where the reagent does not show appreciable absorbance. Therefore, analytical wavelength $390 \mathrm{~nm}$ was used for all measurements.

\section{Effect of $\mathrm{pH}$}

The effect of $\mathrm{pH}$ on the colour reaction was studied and the optimum $\mathrm{pH}$ was established for the reaction mixture by employing the recommended procedure. A plot was made between $\mathrm{pH}$ and absorbance of the complex at $390 \mathrm{~nm}$ and shown in Fig. 4.

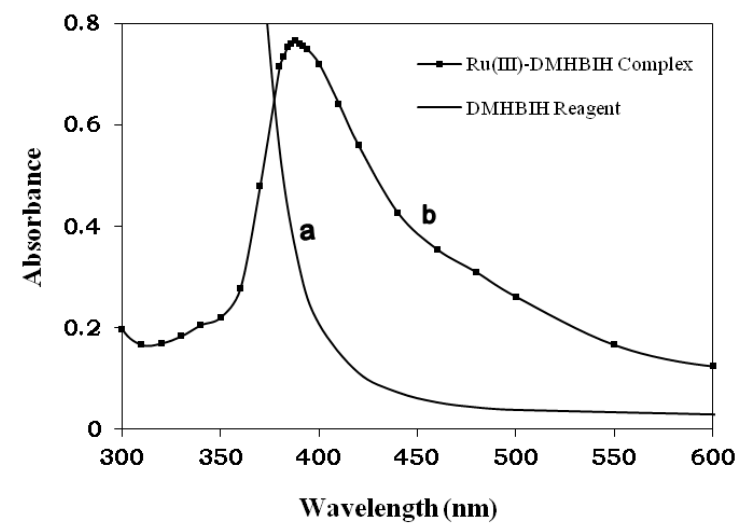

Fig. 3 Zero order absorption spectra.

a) Reagent DMHBIH vs. water blank. b) $\mathrm{Ru}(\mathrm{III})-\mathrm{DMHBIH}$ complex $v s$. reagent blank. $\mathrm{Ru}(\mathrm{III})=4.043 \mu \mathrm{g} / \mathrm{mL}, \quad \mathrm{DMHBIH}=$ $4 \times 10^{-4} \mathrm{M}$, buffer $\mathrm{pH}=4.25$, Triton $\mathrm{X}-100=$ $0.2 \%$.

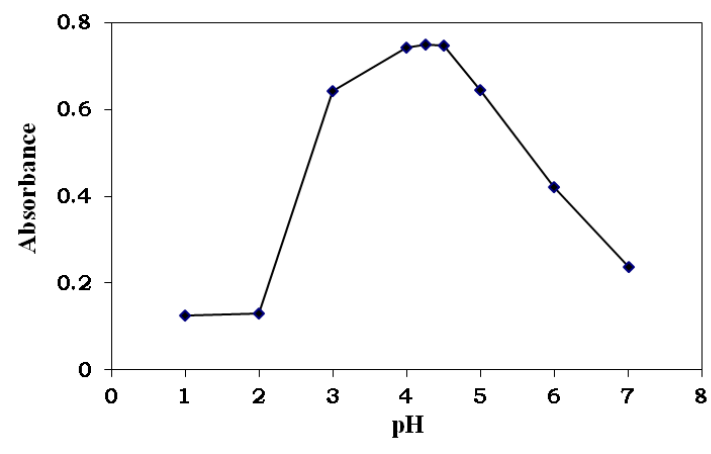

Fig. 4 Effect of $\mathrm{pH}$ on the absorbance of the $\mathrm{Ru}(\mathrm{III})-\mathrm{DMHBIH}$ complex. $\mathrm{Ru}(\mathrm{III})=4.043 \mu \mathrm{g} / \mathrm{mL}$, $\mathrm{DMHBIH}=4 \times 10^{-4} \mathrm{M}$, buffer $\mathrm{pH}=1.0-7.0$, Triton $\mathrm{X}-100=0.2 \%$, wavelength $=390 \mathrm{~nm}$.

Ruthenium(III) reacts with DMHBIH in acidic buffer to give a brownish yellow coloured water soluble complex. The colour reaction between ruthenium(III) and DMHBIH was instantaneous even at room temperature in the $\mathrm{pH}$ range 2.0 to 6.0 , the maximum colour intensity is observed at $\mathrm{pH} 4.25$. Hence, $\mathrm{pH}$ 4.25 was kept constant throughout the experiment.

\section{Effect of time}

The absorbance of the solution was measured at different time intervals to ascertain the stability of the coloured complex. The colour reaction between $\mathrm{Ru}(\mathrm{III})$ and DMHBIH is instantaneous at room temperature. A slow decrease in absorbance of the coloured species is observed after 20 minutes. The stability of the complex was increased by adding neutral surfactant. The absorbance of the $\mathrm{Ru}(\mathrm{III})$ DMHBIH complex remains constant more than $3 \mathrm{~h}$ in presence of the neutral surfactant Triton X-100.

\section{Effect of surfactants}

The effect of various surfactants such as Triton X-100, sodium dodecyl benzene sulphonate (SDBS) and cetyl trimethyl ammonium bromide (CTAB) on the absorption profiles of the Ru(III)-DMHBIH system has been investigated and presented in Table 2 . In presence of Triton X-100 the complex is more stable and exhibited maximum absorbance. Hence, Triton $\mathrm{X}-100$ is selected for further studies.

Table 1 Characteristics of DMHBIH complexes in solution.

\begin{tabular}{|c|c|c|c|c|c|}
\hline Metal ion & $\lambda_{\max }(\mathrm{nm})$ & $\mathrm{pH}$ & Surfactant used & Colour of the complex & 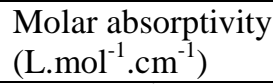 \\
\hline $\begin{array}{l}\mathrm{Pd}(\mathrm{II}) \\
\mathrm{Cu}(\mathrm{II}) \\
\mathrm{Au}(\mathrm{III}) \\
\mathrm{Ru}(\mathrm{III})\end{array}$ & $\begin{array}{l}382 \\
400 \\
384 \\
390\end{array}$ & $\begin{array}{l}5.5 \\
8.0 \\
4.0 \\
4.25\end{array}$ & $\begin{array}{l}\text { Triton X-100 } \\
\text { Triton X-100 } \\
\text { SDBS } \\
\text { Triton X-100 }\end{array}$ & $\begin{array}{l}\text { Bright yellow } \\
\text { Bright yellow } \\
\text { Yellow } \\
\text { Brownish yellow }\end{array}$ & $\begin{array}{l}2.44 \times 10^{4} \\
1.08 \times 10^{4} \\
2.9 \times 10^{4} \\
1.7 \times 10^{4}\end{array}$ \\
\hline
\end{tabular}




\section{Effect of Triton $X-100$}

A study on the effect of volume of Triton X-100 on the absorbance of the complex indicates that absorbance of the metal complex remains constant over a range of $1.0 \mathrm{~mL}$ to $4.0 \mathrm{~mL}$ of Triton $\mathrm{X}-100$ (5\%). Therefore, $1.0 \mathrm{~mL}$ of Triton $\mathrm{X}-100(5 \%)$ was sufficient in all analytical studies. Triton X-100 serves to stabilize and sensitize the metal complex.

\section{Effect of DMHBIH concentration}

On varying the volume of reagent DMHBIH $\left(1 \times 10^{-2} \mathrm{M}\right)$ from $0.5 \mathrm{~mL}$ to $4.0 \mathrm{~mL}$, constant absorbance was obtained from $1.0 \mathrm{~mL}$ to $4.0 \mathrm{~mL}$. Therefore, a 10-fold molar excess of DMHBIH reagent is essential for complete and constant colour development. Excess of reagent has no effect on the absorption of the complex.

\section{Order of addition of reactants}

The order of addition of metal ion, DMHBIH reagent, buffer solution and surfactant has no adverse effect on the absorbance of the Ru(III)-DMHBIH coloured complex.

\section{Calibration graphs and analytical characteristics}

The system obeyed Beer's law in the range 0.202 to $4.043 \mu \mathrm{g} / \mathrm{mL}$ of $\mathrm{Ru}(\mathrm{III})$ with excellent linearity in terms of correlation coefficient value $(r=0.99)$. However, the practical range of determination of $\mathrm{Ru}$ (III) obtained from Ringbom's curve is 0.809 to $3.639 \mu \mathrm{g} / \mathrm{mL}$ at $390 \mathrm{~nm}$. The molar absorptivity and Sandell's sensitivity of the Ru(III)-DMHBIH complex are $\quad 1.7 \times 10^{4} \mathrm{~L} \cdot \mathrm{mol}^{-1} . \mathrm{cm}^{-1}$ and $\quad 0.006 \mu \mathrm{g} . \mathrm{cm}^{-2}$, respectively. The specific absorptivity of the complex is $0.17 \mathrm{~mL} \cdot \mathrm{g}^{-1} \cdot \mathrm{cm}^{-1}$. The precision of the method in terms of relative standard deviation $(n=10)$ for the determination of $2.021 \mu \mathrm{g} / \mathrm{mL}$ of $\mathrm{Ru}$ (III) is $0.03 \%$. Important analytical parameters of $\mathrm{Ru}(\mathrm{III})-\mathrm{DMHBIH}$ are summarized in Table 3.

\section{Composition and stability of the complex}

The composition of the complex is determined by Job's continuous variation method and mole ratio method and found to be $1: 1[\mathrm{Ru}(\mathrm{III})$ : DMHBH]. The stability constant of the complex is determined as $1.82 \times 10^{6}$ by Job's method.

Derivative spectrophotometry is a useful technique because it decreases the interference, i.e. increases the tolerance limit value of foreign ions and may be advantageously used for the determination of metal ion having overlapping spectra. The conceptual simplicity, relatively quick and easy realization, increased selectivity in the analysis of minor components, are the main reasons why the interest in derivative spectra is constantly growing for practical applications. The recommended derivative procedure has been employed for the determination of $\mathrm{Ru}(\mathrm{III})$ using DMHBIH.

The first order and second order derivative spectral graphs are shown in Fig. 5 and Fig. 6, respectively. This shows that, the derivative amplitude measured at $426 \mathrm{~nm}$ for first order and $438 \mathrm{~nm}$ for second order were found to be proportional to the amount of ruthenium(III).

Table 2 Effect of various surfactants on the Ru(III)-DMHBIH complex.

\begin{tabular}{l|l|l}
\hline Surfactant $(5 \%)$ & $\begin{array}{l}\text { Nature } \\
\text { of surfactant }\end{array}$ & Absorbance at $390 \mathrm{~nm}$ \\
\hline None & - & 0.685 \\
Triton X-100 & Neutral & 0.760 \\
CTAB & Cationic & 0.628 \\
SDBS & Anionic & 0.470 \\
\hline
\end{tabular}

Table 3 Important analytical parameters of the Ru(III)-DMHBIH complex.

\begin{tabular}{l|l|l|l}
\hline Parameter & \multicolumn{3}{|c}{ Results } \\
\cline { 2 - 4 } & Zero order & First order derivative & Second order derivative \\
\hline$\lambda_{\max }(\mathrm{nm})$ & 390 & 426 & 438 \\
Detection limit $(\mu \mathrm{g} / \mathrm{mL})$ & 0.0846 & - & - \\
Limit of quantization $(\mu \mathrm{g} / \mathrm{mL})$ & 0.2537 & - & - \\
Beer's law range $(\mu \mathrm{g} / \mathrm{mL})$ & $0.202-4.043$ & $0.202-4.447$ & $0.202-4.447$ \\
Regression equation $Y=\mathrm{a}+\mathrm{b} x$ & & & \\
Slope $(\mathrm{b})$ & 0.1631 & 0.0398 & 0.0218 \\
Intercept $(\mathrm{a})$ & 0.0791 & 0.0296 & 0.0191 \\
Correlation coefficient $(r)$ & 0.9988 & 0.9981 & 0.9971 \\
\hline
\end{tabular}




\section{Effect of diverse ions}

The effect of various diverse ions in the determination of $\mathrm{Ru}(\mathrm{III})$ was studied to find out the tolerance limit of foreign ions in the present method. The tolerance limit of a foreign ion was taken as the amount of foreign ion required to cause an error $\pm 2 \%$ in the absorbance or amplitude. The results are given in Table 4 .

The data obtained in the derivative method is also incorporated. The data suggests that larger amounts of many anions such as bromide, iodide and urea do not interfere when they present more than $1000 \mu \mathrm{g} / \mathrm{mL}$.

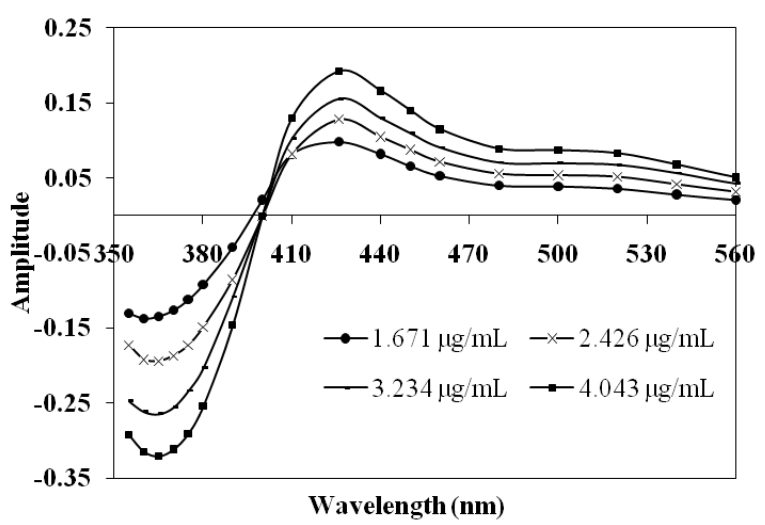

Fig. 5 Typical first order derivative spectra of $\mathrm{Ru}(\mathrm{III})-\mathrm{DMHBIH}$ complex vs. reagent as blank. $\quad \mathrm{Ru}(\mathrm{III})=1.671, \quad 2.426, \quad 3.234$, $4.043 \mu \mathrm{g} / \mathrm{mL}$, DMHBIH $=4 \times 10^{-4} \mathrm{M}$, buffer $\mathrm{pH}=4.25$, Triton $\mathrm{X}-100=0.2 \%$.

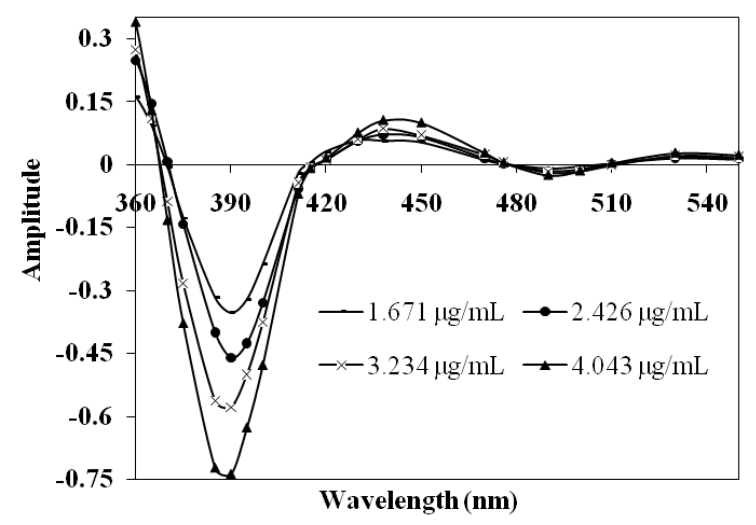

Fig. 6 Typical second order derivative spectra of $\mathrm{Ru}(\mathrm{III})-\mathrm{DMHBIH}$ complex vs. reagent as blank. $\mathrm{Ru}(\mathrm{III})=1.671,2.426,3.234$, $4.043 \mu \mathrm{g} / \mathrm{mL}$, DMHBIH $=4 \times 10^{-4} \mathrm{M}$, buffer $\mathrm{pH}=4.25$, Triton $\mathrm{X}-100=0.2 \%$.
Table 4 Tolerance limit of foreign ion in the determination of $2.021 \mu \mathrm{g} / \mathrm{mL}$ of $\mathrm{Ru}(\mathrm{III})$.

\begin{tabular}{|c|c|c|c|}
\hline \multirow[t]{2}{*}{ Ion added } & \multicolumn{3}{|c|}{ Tolerance limit $(\mu \mathrm{g} / \mathrm{mL})$} \\
\hline & $\begin{array}{l}\text { Zero } \\
\text { order }\end{array}$ & $\begin{array}{c}\text { First } \\
\text { order }\end{array}$ & $\begin{array}{c}\text { Second } \\
\text { order }\end{array}$ \\
\hline Bromide & 3196 & 3196 & 3196 \\
\hline Iodide & 1523 & 2030 & 2030 \\
\hline Urea & 1086 & 1207 & 1207 \\
\hline Sulphate & 576 & 1537 & 1537 \\
\hline Nitrate & 248 & 496 & 496 \\
\hline Tetraborate & 246 & 491 & 491 \\
\hline Phosphate & 152 & 760 & 760 \\
\hline Thiocyanide & 93 & 465 & 465 \\
\hline Ascorbic acid & 71 & 141 & 141 \\
\hline Fluoride & 61 & 152 & 152 \\
\hline Tartarate & 53 & 60 & 60 \\
\hline oxalate & 25 & 352 & 352 \\
\hline Thiourea & 3.0 & 3.0 & 3.0 \\
\hline $\mathrm{Ba}(\mathrm{II})$ & 192 & 275 & 275 \\
\hline $\operatorname{Mg}(\mathrm{II})$ & 150 & 150 & 200 \\
\hline $\mathrm{Zn}(\mathrm{II})$ & 131 & 157 & 157 \\
\hline $\mathrm{Mn}(\mathrm{II})$ & 101 & 132 & 132 \\
\hline $\mathrm{La}(\mathrm{III})$ & 83 & 111 & 111 \\
\hline $\mathrm{W}(\mathrm{VI})$ & 74 & 74 & 110 \\
\hline $\mathrm{Co}(\mathrm{II})$ & 71 & 94 & 94 \\
\hline $\mathrm{Pb}(\mathrm{II})$ & 66 & 83 & 90 \\
\hline $\mathrm{Rh}(\mathrm{II})$ & 60 & 60 & 84 \\
\hline $\operatorname{Sr}(\mathrm{II})$ & 53 & 70 & 70 \\
\hline Bi(III) & 42 & 42 & 42 \\
\hline $\mathrm{Zr}(\mathrm{IV})$ & 37 & 55 & 55 \\
\hline $\mathrm{Cd}(\mathrm{II})$ & 36 & 54 & 54 \\
\hline $\mathrm{Hg}(\mathrm{II})$ & 16 & 80 & 80 \\
\hline $\operatorname{Sn}(\mathrm{II})$ & 14 & 95 & 95 \\
\hline U(VI) & 10 & 48 & 48 \\
\hline $\mathrm{Ni}(\mathrm{II})$ & 9.0 & 14 & 14 \\
\hline $\operatorname{Ag}(\mathrm{I})$ & 9.0 & 22 & 22 \\
\hline Os(VIII) & 6.0 & 6.0 & 10 \\
\hline $\mathrm{Se}(\mathrm{IV})$ & 6.0 & 32 & 32 \\
\hline $\mathrm{Pd}(\mathrm{II})$ & 6.0 & 6.0 & 6.0 \\
\hline $\mathrm{Li}(\mathrm{I})$ & 4.0 & 7.0 & 7.0 \\
\hline Mo(VI) & 4.0 & 15 & 23 \\
\hline $\mathrm{Cu}(\mathrm{II})$ & $0.3,4.0^{\mathrm{a}}$ & $1.0,5.0^{\mathrm{a}}$ & $1.0,5.0^{\mathrm{a}}$ \\
\hline $\mathrm{Al}(\mathrm{III})$ & 3.0 & 5.0 & 5.0 \\
\hline Ti(IV) & 3.0 & 4.0 & 4.0 \\
\hline $\mathrm{Ce}(\mathrm{IV})$ & 2.2 & 11 & 11 \\
\hline $\mathrm{Fe}(\mathrm{III})$ & $2.2^{\mathrm{b}}$ & $4.0^{b}$ & $4.0^{\mathrm{b}}$ \\
\hline $\mathrm{V}(\mathrm{V})$ & 1.0 & 1.0 & 2.0 \\
\hline $\mathrm{Cr}(\mathrm{VI})$ & 0.4 & 1.0 & 1.0 \\
\hline $\mathrm{Sb}(\mathrm{III})$ & 0.2 & 0.4 & 2.0 \\
\hline As(III) & 0.2 & 1.0 & 1.0 \\
\hline
\end{tabular}

Sulphate, nitrate, tetraborate and phosphate were tolerable more than $150 \mu \mathrm{g} / \mathrm{mL}$. Cations such as barium(II), magnesium(II), zinc(II) and manganese(II) do not interfere when they are present up to $100 \mu \mathrm{g} / \mathrm{mL}$. Lanthanum(III), tungsten(VI), cobalt(II), lead(II), rhodium(II) and strontium(II) were tolerable 
more than $50 \mu \mathrm{g} / \mathrm{mL}$ in the determination of ruthenium(III) using DMHBIH. However, metals like vanadium(V), chromium(VI), antimony(III) and arsenic(III) are seriously interfered. The interference of associated metal ions such as copper(II) and iron(III) was decreased with masking agents thiourea and fluoride respectively.

\section{Applications}

The spectrophotometric determination of $\mathrm{Ru}$ (III) in synthetic alloy samples and real water samples were carried out by employing the recommended procedure. A known aliquot of the sample solution was taken in a $25-\mathrm{mL}$ volumetric flask containing $10 \mathrm{~mL}$ of buffer $\mathrm{pH} 4.25,1.0 \mathrm{~mL}$ of Triton $\mathrm{X}-100(5 \%)$ and $1.0 \mathrm{~mL}$ of DMHBIH reagent $1 \times 10^{-2} \mathrm{M}$ reagent solutions. The contents in the flask were made up to the mark with distilled water. The amount of ruthenium(III) present in these samples was computed from a predetermined calibration plot and results are summarized in Table 5.

\section{Conclusions}

The present method, using DMHBIH as spectrophotometric reagent for the determination of $\mathrm{Ru}(\mathrm{III})$ in presence of Triton $\mathrm{X}-100$ was considerably superior to other spectrophotometric methods, when comparing analytical parameters viz. linear range and molar absorptivity (see Table 6).

Most of the spectrophotometric methods involve both extraction and heating of the reaction mixture [13-15] or only heating [16,17]. The organic solvents used for the extraction process, such as benzene and chloroform, are often carcinogenic, toxic and cause environmental pollution. Heating at a specific temperature for a long time is laborious and time consuming. The present method is not laborious and there is no need of heating the components or preextraction. Further, the Triton X-100 enhances the stability of the metal complex. Moreover, the present method is simple, rapid, reasonably sensitive and selective for the determination of ruthenium(III).

Table 5 Determination of $\mathrm{Ru}(\mathrm{III})$ in synthetic alloy samples and real water samples by present method.

\begin{tabular}{|c|c|c|c|c|c|c|c|}
\hline \multirow[t]{2}{*}{ Sample } & \multirow{2}{*}{$\begin{array}{c}\text { Amount of } \\
\mathrm{Ru}(\mathrm{III}) \text { added } \\
(\mu \mathrm{g} / \mathrm{mL})\end{array}$} & \multicolumn{3}{|c|}{$\begin{array}{l}\text { Amount of } \mathrm{Ru}(\mathrm{III}) \text { found }^{\mathrm{b}} \\
(\mu \mathrm{g} / \mathrm{mL})\end{array}$} & \multicolumn{3}{|c|}{$\operatorname{RSD}(\%)$} \\
\hline & & $\begin{array}{l}\text { Zero } \\
\text { order }\end{array}$ & $\begin{array}{l}\text { First } \\
\text { order }\end{array}$ & $\begin{array}{l}\text { Second } \\
\text { order }\end{array}$ & $\begin{array}{l}\text { Zero } \\
\text { order }\end{array}$ & $\begin{array}{l}\text { First } \\
\text { order }\end{array}$ & $\begin{array}{l}\text { Second } \\
\text { order }\end{array}$ \\
\hline $\begin{array}{l}\mathrm{Zn}-\mathrm{Mg} \text { alloy sample } \\
(\mathrm{Zn}, 50 \mathrm{mg}+\mathrm{Mg}, 50 \mathrm{mg})\end{array}$ & 5.0 & 5.14 & 5.11 & 5.12 & -2.8 & -2.2 & -2.4 \\
\hline $\begin{array}{l}\mathrm{Zn}-\mathrm{Mg} \text { alloy sample } \\
(\mathrm{Zn}, 20 \mathrm{mg}+\mathrm{Mg}, 20 \mathrm{mg})\end{array}$ & 3.5 & 3.36 & 3.39 & 3.45 & +4.0 & +3.1 & +1.4 \\
\hline Synthetic alloy sample $(\mu \mathrm{g} / \mathrm{g})^{\mathrm{a}}$ & 2.2 & 2.28 & 2.26 & 2.25 & -3.6 & -2.7 & -2.2 \\
\hline River water sample & 0.61 & 0.62 & 0.63 & 0.62 & +1.6 & -3.2 & -1.6 \\
\hline Pond water sample & 0.61 & 0.63 & 0.60 & 0.62 & +3.2 & +1.6 & -1.6 \\
\hline
\end{tabular}

${ }^{\mathrm{a}} \mathrm{Pb}(\mathrm{II}),(0.8)+\mathrm{Co}(\mathrm{II}),(20.0)+\mathrm{Os}(\mathrm{VIII}),(0.8)+\mathrm{Rh}(\mathrm{II}),(100)$;

${ }^{\mathrm{b}}$ average of best three among five determinations

Table 6 Comparison of spectrophotometric methods for the determination of ruthenium(III).

\begin{tabular}{|c|c|c|c|c|c|c|}
\hline Reagent & $\begin{array}{l}\lambda_{\max } \\
(\mathrm{nm})\end{array}$ & $\mathrm{pH}$ & $\begin{array}{l}\text { Beer's law } \\
\text { range }\end{array}$ & $\begin{array}{l}\text { Molar } \\
\text { absorptivity } \\
\left(\text { L.mol }{ }^{-1} \cdot \mathrm{cm}^{-1}\right)\end{array}$ & Extraction / heating & Ref. \\
\hline $\begin{array}{l}\text { Res-acetophenone } \\
\text { guanylhydrazone }\end{array}$ & 375 & 1.5 & $0-35.0 \mathrm{ppm}$ & $0.74 \times 10^{4}$ & Aqueous & {$[5]$} \\
\hline Tropolone & 415 & 4.0 & $0-5.7 \mathrm{ppm}$ & $1.87 \times 10^{4}$ & $\begin{array}{l}\text { Extn. } \mathrm{CHCl}_{3} \text {, heated } \\
\text { at } 100{ }^{\circ} \mathrm{C}\end{array}$ & {$[13]$} \\
\hline $\begin{array}{l}\text { 3-Nitroso-4-hydroxy-5,6- } \\
\text { benzocoumarin }\end{array}$ & 520 & $5.5-8.0$ & $1-7.4 \mathrm{ppm}$ & $1.04 \times 10^{4}$ & $\begin{array}{l}\text { Extn. BtOH } 20 \mathrm{~min} \text {, } \\
\text { heated at } 100^{\circ} \mathrm{C}\end{array}$ & {$[14]$} \\
\hline $\begin{array}{l}\text { 3-(2-Pyridyl)-5,6-diphynyl- } \\
\text { 1,2,4-triazine }\end{array}$ & 485 & 5.0 & 0.5-3.4 ppm & $2.1 \times 10^{4}$ & $\begin{array}{l}\text { Heated } 30 \text { min at } \\
85^{\circ} \mathrm{C} \text {, extracted }\end{array}$ & {$[15]$} \\
\hline $\begin{array}{l}\text { 4-5-diamino-6-hydroxy } \\
\text { pyrimidine sulphate }\end{array}$ & 530 & $\begin{array}{l}\text { Acedic } \\
\text { medium }\end{array}$ & - & $6.5 \times 10^{3}$ & Heated & {$[16]$} \\
\hline $2,2^{\prime}, 2^{\prime} '$ - terpyridine & 690 & $3.0-4.5$ & 2-10 ppm & $8.3 \times 10^{3}$ & Heated $2 \mathrm{~min}$ at $80^{\circ} \mathrm{C}$ & [17] \\
\hline $\begin{array}{l}\text { 3-Hydroxy-2-methyl- sodium } \\
\text { isoamylxantahte }\end{array}$ & 350 & $4.5-7.0$ & $3.5-7.7 \mu \mathrm{g} / \mathrm{mL}$ & $1.18 \times 10^{4}$ & Aqueous & {$[18]$} \\
\hline $\begin{array}{l}3,5 \text {-dimethoxy-4- } \\
\text { hydroxybenzaldehyde } \\
\text { isonicotinoyl hydrazone }\end{array}$ & 390 & 4.25 & $\begin{array}{l}0.202-4.043 \\
\mu \mathrm{g} / \mathrm{mL}\end{array}$ & $1.07 \times 10^{4}$ & Aqueous & $\begin{array}{l}\text { Present } \\
\text { method }\end{array}$ \\
\hline
\end{tabular}


M. Rameswara Rao et al., Determination of ruthenium(III) in the presence of micellar medium by derivative ...

\section{References}

[1] R.B. Singh, P. Jain, R.P. Singh, Talanta 29 (1982) 77-84.

[2] V. Kiran Kumar, M. Rameswra Rao, K.B. Chandrasekhar, N. Devanna, Asian J. Chem. 20 (2007) 2197-2204.

[3] J. Pramanic, J.P. Ghosh, M. Mazumdar, H.S. Das, J. Indian Chem. Soc. 58 (1981) 235-238.

[4] S. Pal Chaudhury, S.C. Shome, J. Indian Chem. Soc. 68 (1991) 430-431.

[5] S.G. Kawatkar, P.S. Manoli, Acta Cienc. Indica, Chem. 24 (1998) 109-110.

[6] Anitha Varghese, A.M.A. Khadar, Acta Chim. Slov. 53 (2006) 374-380.

[7] K.B. Chandrasekhar, K. Hussain Reddy, T. Sreenivasulu Reddy, J. Indian Chem. Soc. 80 (2003) 930-933.

[8] K.B. Chandrasekhar, K. Hussain Reddy, Indian J. Chem. 41 (2002) 1643-1645.

[9] M. Rameswara Rao, K.B. Chandrasekhar, N. Devanna, Arch. Appl. Sci. Res. 3 (2011) 462-471.
[10] Z. Marczenko, Spectrophotometric Determination of Elements, John Wiley and Sons Inc., New York, ${ }^{\text {st }}$ Ed., 1976.

[11] F.W. Fifield, P.J. Haines. (Eds.), Environmental Analytical Chemistry, Blackwell Science, 2000, pp. 378-380.

[12] J.P. Phillips, L.L. Merritt, J. Am. Chem. Soc. 70 (1948) 410-411.

[13] G.H. Rizvi, B.P. Gupta, R.P. Singh, Anal. Chim. Acta 54, (1971) 295-302.

[14] N. Kohili, R.P. Singh, Talanta 21 (1974) 638-641.

[15] C. Lal Kamara, H. Gilbert Ayres, Anal. Chim. Acta 78 (1975) 423-429.

[16] C.G. Raghu Veer, T. Rhodes, C.W. McDonald, Microchimica Acta 62 (1974) 611-616.

[17] C. Lal Kamara, H. Gilbert Ayres, Anal. Chim. Acta 81 (1976) 117-129.

[18] A.K. Malik, K.N. Kaul, B.S. Lark, W. Faubel, A.L.J. Rao, Turk. J. Chem. 25 (2001) 99-105. 